Volume 28, 2018

http://journals.sfu.ca/cjsdw

\title{
Article
}

\section{Scenes from Graduate School: Playing in the Smooth Spaces of Academic Writing}

\author{
Nancy Bray \\ Office of Interdisciplinary Studies, University of Alberta
}

\section{Abstract}

In this essay, I describe how I have experienced difficulties writing in particular academic genres. Finding spaces to play in these genres has helped me to ease these difficulties and negotiate the conflicts and contradictions of the academy. To explore and explain innovative spaces within genres, I extend Deleuze and Guattari's notion of smooth and striated spaces with work in rhetorical genre studies. I conclude that opening smooth spaces in striated academic genres is not only important for students like me but may also help us better respond to the changing realities of graduate studies and academic work in Canada. I offer some suggestions as to how writing studies scholarship could support these efforts.

"Writing about a writer's block is better than not writing at all." -Charles Bukowski, The Last Night of the Earth Poems

\section{Part 1: Initiation}

The words dance in the air above me, invisible. I sit still, close my eyes, reach for them. I pull the words through me to my fingers, to my keyboard, to the screen. These words ring with rightness; they reveal the rhythm of the next sentence. As they gather on the screen, my destination starts to emerge: primitive, uncertain. I do not know where I am going; I do not know exactly what I am going to say. But the colours deepen and lines become sharper as I draw closer to this far-off 
Volume 28, 2018

http://journals.sfu.ca/cjsdw

landscape. Words, sentences, and the shapes of thoughts appear. Writing is an act of faith, I remind myself. I close my eyes and probe for more words, and they sing the world.

I sit still, eyes closed, and I reach for the words. I fumble, I grasp, I prod. I open my eyes, furrow my brow. The words do not come to me, through me. They fall, clatter on the keyboard, separate, unattached. I struggle to pull them together. I shuffle them around, rewrite sentences, shift paragraphs. I move back and forth between the research articles that I try to mimic and my own writing. There is no space in this genre to play, I tell myself. So I hold back, tamp down my instinct to pull the words from the air through me, to let the writing find its own shape. I fret because no foggy landscape emerges from the hail of words on my keyboard. Writing is an act of faith, I tell myself. But I have no faith here. I do not trust these words. They are uncertain, entangled in my doubt, disconnected. No, no, no, I say to myself. Writing is an act of persistence. I chip away at the essay. The words fill the page; I do not believe them.

How do I feel such joy and ease when writing certain pieces and such disconnection and discomfort when writing others? Why do my strategies to deal with the challenges of writing succeed in one case and fail in another? Why do I identify so profoundly with one type of writing and feel dissatisfied and betrayed by another?

As a writing instructor and $\mathrm{PhD}$ Candidate in an interdisciplinary program that includes writing studies, I know that feeling stuck while writing is not unusual, even for advanced academic writers. As Hairston (1986) points out, it is often those of us invested in writing-writing instructors-who experience the most difficulty. We know better than anyone the risks of putting our words to paper, "we expose what we are by writing," as Hairston suggests (p. 63).

Nevertheless, I am disappointed by this latest bout of writing difficulty. I have gone to great lengths to overcome my struggles with academic writing (a doctorate in writing studies!), and I have built a well-stocked-if not overflowing—toolbox for dealing with writing difficulties. Or so I thought. Sadly, however, none of the strategies that have worked for me in the past seemed to ease my suffering as I wrote a chapter of my dissertation. Like the piece that I wrote comfortably, this difficult chapter was one of the four discrete articles that will form my dissertation. This dissertation-by-publication structure allows me to explore my research area-the impact of written genres on climate change communication-from various perspectives while publishing my work in academic journals as I continue to write. Although I worked on and completed both chapters 
Volume 28, 2018

http://journals.sfu.ca/cjsdw

simultaneously, these pieces differed in one important aspect: the academic genre in which I was writing. I suffered while writing a citation content analysis study, and I happily wrote an experimental personal essay on the relationship between my interest in climate change and my Canadian national identity. The citation content analysis examined how a research article on climate change was directly and indirectly quoted in online news articles. This type of research question and method are typically written in the Introduction-Method-Results-and-Discussion (IMRaD) research article genre, which begins by contextualizing the research question within a discipline or societal issue, moves to a presentation of the form and results of the study, and ends with a return to the broader implications of the research. In contrast, the essay on my research interests and national identity called for no particular structure: I was free as a writer to find an approach to explore this issue. It was precisely this difference in genre, I will argue here, that caused these writing experiences to diverge so significantly.

According to rhetorical genre scholarship, genre is where individual writers meet the community for whom they are writing. This scholarship emphasizes the situational and social nature of genre. In her influential work on genre, Miller (1984) notes that patterned rhetorical behaviours (genres) develop in response to repeated situations. Building on this idea, later research observed that genres aim to achieve the particular goals of interlocutors working together in a community. The research of Bazerman (1988) and Swales (1990), for instance, has explored how academic genres, in particular the academic research article, accomplish the social purposes of the academic community. Because genres are closely tied to a community's purposes (both rhetorical and material), they come to reflect the epistemological stance and power relationships within the group (Devitt, 2004). The worldview of the community is perpetuated, as Berkenkotter and Huckin (1995) argue, through a duality of structure: we use genres to structure our experiences, but they, in turn, will cause us to reproduce experiences as the structures we expect to see. Yet despite this power to perpetuate social structures, genres are also inherently unstable and local: they must be "stabilized-for-now or stabilized-enough" (Schryer, 1994, p. 89) to be recognized by community members, but they must also adapt to local and changing purposes.

When writers encounter a new genre, they must grapple with the hidden historical depths and the precarious stability of these rhetorical patterns of behaviours. While the writer is not without agency in these circumstances and can make choices about how to engage a particular genre, writers must nevertheless "learn the manners" of the community who uses the genre, and there may be consequences for violating these tacit rules (Freadman, 1987). Invariably, mastering a 
Volume 28, 2018

http://journals.sfu.ca/cjsdw

genre-learning these good manners-is part of integrating into and becoming an expert in a discourse community. Writing, therefore, not only exposes what we are, but it also reveals where we belong (or where we don't).

In the following autobiographical scenes and reflections, I will explore how I have learned (wrestled with, resisted, acquiesced to) the manners of the academic community and its written genres. At each stage of this twenty-year long journey, I have had to negotiate different constellations of the social and linguistic pressures that shape academic genres. These different constellations have either hindered or advanced my graduate school journey as I wrestled with the peculiar bind of academic writing: how could I find a way to assert agency and offer originality while observing the strict genre conventions of the academic communities to which I aspired to belong?

I describe how the first stage of my learning journey-a completed Master's degree and one year of a PhD program in comparative literature in the 1990s-was marked by profound confusion and difficult experiences with academic writing. After I abandoned that first PhD program, I worked in the margins of academia for 15 years, following a different career path but always looking back at the university. It was in this liminal and ambiguous space of my journey that I began to play with my academic writing by mixing personal narrative with critical analysis. In this writing, I worked to open up what I call the "smooth spaces" (nomadic spaces without marked paths) within the "striated spaces" (settled, demarcated spaces) of academic genres. (This typology of internal genre spaces follows philosophers Deleuze and Guattari's analysis (1987) of these phenomena in other media such as music and textile arts.) For me, writing in the smooth spaces of academic genres gave me a place to play, a liminal place where I could practice "free assimilation, without accommodation" and I could "combine elements of the familiar and defamiliarize them," as Piaget and Turner define play (Turner, 1982, p. 34). This liminal, playful writing helped me to overcome some of the pressure and contradictions of academic work.

In the latest and final stage of my journey, I returned to the university four years ago to complete an interdisciplinary $\mathrm{PhD}$ that focuses on writing studies. Here, I have continued to struggle with academic writing: I am drawn to smooth genre spaces, where narrative and analysis are combined, but this type of writing can be marginalized and seen as less serious than the intellectual work conducted in traditional academic genres. The difficult writing experience that I describe at the beginning of this piece occurred when I chose to work in a traditional genre to confirm my 
Volume 28, 2018

http://journals.sfu.ca/cjsdw

membership in the academic community, only to find that my strategies for play were ineffective in this space.

While I recognize that my story is unique, I hope by recounting it I will reveal some of the complexities of graduate student writing and provide insight into the various permutations of the journey from novice to advanced academic writer. By shining light on these complexities, I hope to help other graduate students on this journey. To this end, I conclude this essay with some thoughts on how writing studies scholarship might act upon these insights and further support the development of this smooth space in academic writing, particularly in the face of the changing nature of graduate studies and university work in Canada.

\section{Part 2: Confusion}

The strobe light on the dance floor carves up the dancers. Slightly drunk, I watch as the arms, legs, heads, bodies of some students and a professor in my graduate program are remixed and recombined: a slow-motion Picasso painting. This club, hidden in the back alleys of downtown, is not far from the bookstore where, as a girl, I tenderly held the books in the Little House on the Prairie series that I had yet to read. Oddly, it is this love of words and stories that has taken me to this strange place. But, I think to myself, this is not what I thought graduate school would be.

After several years away completing an undergraduate degree and travelling, I'm back in my hometown working on a Master's degree in comparative literature. I did well in my undergraduate degree in linguistics, and my professors had encouraged me to go to graduate school. I had grown tired, however, of the focus on the mechanics of language. I wanted stories back. But I was not prepared for the weight of this degree. Graduate school is dismantling me-I am coming apart.

The dance floor spits out one of my classmates.

"You know, he told me that he really liked your last essay." She tips her head towards our professor. My mumbled response is lost in the noise of the club: I am relieved that my essay has hidden a creeping malaise about what I am learning, that it has concealed the agony of my writing experience. I love the subversion of poststructuralism and deconstruction-the displacement of our notions of a coherent self-but I can't quite rejoice in the radical disconnection of words from the world that the writers of these theories seem to espouse. The texts that we read are dense and seem deliberately obtuse, and our professors strew handfuls of words at us like confetti. What do all these words mean? I ask myself. What do these words have to do with stories? 
Volume 28, 2018

http://journals.sfu.ca/cjsdw

Still, I do my best to mimic their voices. I practice the dense, almost incomprehensible prose, characteristic, in my mind, of good academic writing. "The subject in process is in a cyclical movement, not dialectical, propelled by a continuous process of translation between the body's semiosis and the symbolically-constructed linguistic order," I wrote carefully in my essay, shuffling about these words. Do I know what this means? Can I say why this matters?

"He also said he is surprised that you can dance so well," my classmate laughs as she stumbles back under the pulsing lights. She returns to dance wildly with our professor. They are having an affair, the latest in a long string of affairs that this professor has had with his students. The other dancers, my classmates, shift on the dance floor to accommodate this relationship. Staring into my empty glass, I do wonder whether our casual rapport with meaning is not poisoning us. If we believe the self to be manufactured, unstable, ultimately unknowable, does this give us an excuse to behave however we want? If we throw up a wall of words, what can we hide?

I try to tuck away my uncertainties about what I'm learning and about the behaviour that I am witnessing. But standing there in that room of gyrating, fractured dancers, I know that I am in danger of losing something important.

I'm tired of the thumping music and the blurred dancers. As I leave the club, the winter wind blows through the quiet, familiar streets. A piece of garbage is kicked up by the wind and rattles away.

"Every time a student sits down to write for us, he has to invent the university for the occasion," Bartholomae famously wrote (1985, p. 134). Bartholomae uses this insight to explain the difficulties that undergraduate writers experience when learning academic discourse, the language of the academy. Bartholomae's statement, however, also hints at the protean nature of our conception of the university and its authority. It suggests an instability, a mirage onto which students, faculty, and the public project their conception of human learning and knowledge.

In the first years of my graduate school journey, I imagined the university to be a sacred place, set apart from the ugly uncertainties of human existence. I believed that a graduate degree would grant me the authority of the university, an authority built on the clarity of deeply considered ideas and generalized knowledge. The journey to acquire this authoritative knowledge began in a space and time separated from my previous world. Vaulted classrooms with granite window frames and oak-panelled walls imbued our acts of learning with the sacredness of tradition. From these rooms, 
Volume 28, 2018

http://journals.sfu.ca/cjsdw

I would emerge, I thought, an adult, a rewritten self with clever thoughts and a certain position in this world.

Instead, I found a different invention of the university, one in which human imperfections were all too evident and in which the uncertain and contingent nature of all human knowledge was exposed. The vagaries of the powerful people in that sacred space together with lessons of poststructuralism and deconstruction shattered my worldview. I began to question the teachings of the university as I grew increasingly aware of the disconnection between the words of the academy and its behaviour. Why teach critical theory, which exposes how power unjustly privileges and denies, if you are not prepared to root out abuses of power in your own environment? Why question the traditions and authority of other human institutions-churches and governments-if you do not question the tradition and authority of the university?

Bartholomae (1985) suggests that student writing difficulties often begin with a conflict between the student's own authority and the authority that they must project, and as a result, they feign academic authority using "the voice of a teacher giving a lesson or...the parent giving a lecture at the dinner table" (p. 135). As a graduate student, my conflict was far more nuanced. Unlike Bartholomae's undergraduate writers, I had understood that the manners of the literary criticism genre required that I position myself in relationship to literature in a particular way: I understood what Dias, Freedman, Medway and Paré (2013) call the "epistemic motive" of the literary criticism essay. I had learned that the literary criticism genre "rests on the quality of the mediating critic's sensibility" and that the "critic's persuasiveness...depends in part on establishing a persona of perceptivity, if not brilliance," as Bazerman (1981) explains in his analysis of literary critic Geoffrey Hartman's writing (p. 377). My problem with academic writing did not lie with a failure to properly project the authority of the literary critic; rather, it lay with my uncertainty about the nature and appropriateness of that authority.

Through the teachings of poststructuralism, I had come to accept that my individual understanding of the world would always be limited and that any academic project must acknowledge these limitations while seeking-always imperfectly—to build a broader, consensual understanding of this world. I became increasingly sensitive to the fact that I could not adequately represent any other person's viewpoint; I could only offer my own and hope my revelations might spark recognition and a small moment of insight about the world. For me, these tiny sparks of resonance are the building blocks of shared understanding. My graduate writing, however, asked that I mask the relationship between my individual perspective and my writing, between my 
Volume 28, 2018

http://journals.sfu.ca/cjsdw

identity as a literary critic and my identity outside the university. I was encouraged to develop an academic voice but how that voice revealed itself was limited by the conventions of the literary criticism essay.

Moreover, I had come to believe, perhaps in response to the subtle nihilism of deconstruction, that my words had to do something; they had to act upon the world in some positive way, even if it were only in my behaviour as an individual. Could literary criticism act upon the world differently, more effectively without the affected brilliant persona of the critic? Was our cultivation of the persona of the literary critic related to the abuse of power that I had witnessed? Would I be complicit in this abuse if I also adopted that persona?

I could not easily express these doubts in the genres of my discipline. Like many academic genres, the literary criticism genre is a restricted space, with formal features that (often implicitly) delineate what can and cannot be said. These genres are akin to Deleuze and Guattari's (1987) striated spaces. Striated space is sedentary space; it is a settled, urban space that focuses on arrival, rather than the journey. It "intertwines fixed and variable elements, produces an order and succession of distinct form" (p. 478). It "organizes a matter" (p. 479), and it homogenizes: "The more regular the intersection, the tighter the striation, the more homogenous the space tends to become" (p. 488). According to Savin-Badin (2008), striated learning spaces are characterized by the power of the expert; they reflect a "strong sense of authorship, a sense of clear definition, of outcomes, of a point that one is expected to reach" (p. 13). In these spaces, students cannot challenge disciplinary norms, Savin-Badin suggests; they must conform.

The striations of the literary criticism genre placed me in a classic double bind. My experience reflected the two main characteristics of this phenomenon identified by education theorist Engeström (1987): I received "two messages or commands which deny each other" (think critically about the power structures of institutions but don't question the authority and traditions of the university) and I was unable to make a "meta-communicative statement" about this situation (p. 112). Russell (1997) suggests that this double-bind situation is not unusual for students who encounter conflicts between the various communities (activity systems) of which they are a part. "The development (reconstruction) of individual agency and identity means expanding (or refusing to expand) involvement with an activity system...which requires the appropriation (and sometimes transformation) of certain of its genres," Russell writes. "As individuals are pulled in different directions," he suggests, "they experience double binds manifest in their writing" (p. 534). As graduate students, these "dogs of genre"-as Paré (2002) calls these conflicts that reveal the cracks 
Volume 28, 2018

http://journals.sfu.ca/cjsdw

in our genres-are particularly troublesome: our graduate writing may determine future employment, must satisfy the needs of several audiences, and demands our presence as scholars. The cost for transgressing academic genres may be significant.

How then could I inscribe my emerging philosophies-my growing ideas about the place of my lived experience in my literary criticism-into my paragraphs, my sentences, my words? Under the weight of this question, my invention of the university crumbled; my graduate writing floundered in this emptiness.

\section{Part 3: Marginalization}

I sit at the edge of my dorm room bed, weeping. "I have to quit," I tell him. He is perplexed, his eyebrows lifted in worry. He comes to sit next to me on the bed.

"I don't understand," he says, jabbing my knee with his-hoping, I think, that this silly familiarity would end my tears.

"I have to quit graduate school, the PhD."

"Oooh. Thaaaat."

We are unlikely friends. Him: dark curly hair; irrepressible gait; penchant for leaving anonymous notes in lecture halls claiming that the professor had kidnapped him. Me: dead straight mousy brown hair; glasses far too large for the fashion of the time; penchant for being overly serious and hiding my uncertainty with big words and fancy theories. As the only two Canadian exchange students living in our residence building in Germany, we have been thrown together by circumstance, but a friendship has grown out of a shared love for music, Star Trek: The Next Generation, and German slang.

"What am I going to do? How can I tell my parents? How can I tell my professors?"

"Nancy, you have to do what feels right to you." I nod and sniffle. This is not sophisticated or original advice, but it is what I need to hear. I need to believe I can honour this creeping unease that I have been experiencing. I had first experienced this feeling as I had finished my Master's degreea twinge, a pull, a resistance. I could ignore it in the rush to finish my degree. However, during my year in Germany, the first year of my PhD program in comparative literature, this feeling has grown and other symptoms have appeared. I am besieged by headaches, I can't concentrate, and I have no motivation to do schoolwork for the first time in my life. Something is wrong. 
Volume 28, 2018

http://journals.sfu.ca/cjsdw

My friend is a musician. Sitting in the stairwell of our residence building, listening to him sing and play the guitar in harmony with two other musicians has changed me. I see how music is a part of him: it bubbles out of him, unbidden, and it has the power to mesmerize. It follows a deep root, an unknown path. He plays with his music like a juggler; he tosses it into the air in unexpected and surprising ways that transform the cacophony of an Irish pub into a church-like silence.

My friend's relationship with music stands in stark contrast with the writing that I am doing for graduate school: my writing feels constricted and overly rehearsed. I sense that writing is special for me, and I want a relationship with words like my friend has with music. I want to follow the deep root, to play with my words; I want my writing to transform others. But my writing for graduate school is deadened by so many forces: the fear that if I am not clever, my writing will be insignificant; the belief that I need to write in a distant voice about the literature that I love; an uncertainty about how I could write differently; and the panic that I might fail at graduate school if I tried a different approach.

If I hadn't met my friend and experienced his relationship with music, I probably could have continued in graduate school. But after seeing how he follows his music, I have to ask myself where I would like my writing to go. My writing, I discover, leads away from the university.

My first graduate career ended with a passionate breakup essay, in which I rashly combined personal narrative, pop culture references, and academic analysis. In this hybrid mash of discourses, I found a way out of the bind of the literacy criticism genre. Inspired by my friend's relationship with music, I wrote with abandon about reading Goethe's Sorrows of Young Werther, a story about a love triangle, while experiencing a similar situation in my life. I argued that it was often precisely this entanglement with the reader's own life that made literature such a powerful and meaningful form of human expression. This was the beginning of a transitional, liminal phase of my journey as an academic writer, a phase in which I could freely associate my personal experiences with my academic thought and move beyond the striated spaces of the literary criticism genre and academic writing in general.

My breakup essay concluded with a proud declaration of my intention to leave academia:

The multiple narratives of this essay, with their varying degrees of credibility, have an honesty that my other essays do not. My autobiographical reflections, which normally have no place in literary criticism, are my untethered voice, and I can no longer pretend that I can 
Volume 28, 2018

http://journals.sfu.ca/cjsdw

write in the pseudoscientific costume necessary to procure the scholarships and grants needed to finance my degree and later my career. (Bray, 1997)

Audaciously, I submitted this piece to an unsuspecting professor, who wrote me a short rejoinder asking me to consider staying in graduate school. It was too late; I could not resolve the double bind of academic writing in the vaulted classrooms of the university.

As I contemplated a return to graduate studies years later, I found that my doubts about the university were tightly tangled around my relationship to academic writing. There is no question the intellectual and teacher in me feel at home in the idea-decked classrooms of the university. It's my writerly self who is cautious: in my years of absence, I had developed as a writer, and I was uncertain that I could return to the striated spaces of academic genres. Could I find space at the university to write without having to separate my academic thinking and writing from the other parts of my life?

Slowly, I inched myself closer to the dangerous institution, sticking to its peripheries. I completed a part-time professional Master's degree in communication and technology, and I took a course in composition theory. Taking these small steps, I learned that I was not the only person-by far-who suspected that there might be something important and interesting missing in traditional forms of academic writing, a realization that made a return to the university possible for me.

Criticisms of academic writing, I learned, were common. Academics are accused of producing "dreary monographs, tangled paragraphs and impenetrable sentences" (Limerick, 2005, p. 226) and "impersonal, stodgy, jargon-laden, abstract prose" (Sword, 2012, p. 3). These criticisms often highlight the failure of traditional academic genres to engage audiences both internal and external to the university. However, other scholars point out that writing in traditional academic genres also limits our ways of thinking: making space for alternative forms of academic discourse, they argue, may help us to better explore the nature of our academic work and to make way for new types of scholarship (Behar, 1997/2014 Bizzell, 1999; Ellis, 1995, 2004; Royster, Kirsch, \& Bizzell, 2012; Tompkins, 1987; Williamson, 1997).

Anthropologist Clifford Geertz (2009), for example, observes that he cannot fully describe the nature of his work in traditional academic genres: "We lack the language to articulate what takes place when we are in fact at work. There seems to be a genre missing" (p. 119-20). For Behar (1997/2014), also an anthropologist, recovering Geertz's missing genre involves opening spaces in our existing genres where we can acknowledge and explore the confluence of the subjective 
Volume 28, 2018

http://journals.sfu.ca/cjsdw

(internal) and objective (external) nature of our work as researchers. Behar advocates a more personal form of academic work, one in which the researcher follows explicit connections between her or his own experiences and the research undertaken. Behar's appeal for "vulnerable writing" echoes the work of the expressivist movement in writing studies, in which scholars such as Elbow (2000), Murray (1991), and Bishop (1997) argue for the importance of individual expression in the writing process and in the postsecondary writing classroom. Other writing studies scholars such as Spellmeyer (1989) and Bizzell (1999) suggest that transposing and juxtaposing knowledges from different discourses help us to reveal how power obscures the polyvalence of language. As Royster, Kirsch, and Bizzell (2012) point out, this type of scholarship may create space for modes of being, knowing, and speaking beyond those of the dominant Western, white, and male culture.

"Vulnerable writing" (Behar, 1997/2014) or "hybrid academic discourse" (Bizzell, 1999) works against the striations of traditional academic genres: it works in smooth space, which Deleuze and Guattari (1987) juxtapose with striated space. In contrast to sedentary striated space, smooth space is nomadic. It is "in principle infinite, open, and unlimited in every direction...it does not assign fixed and mobile elements but rather distributes a continuous variation" (p. 475-6); smooth space privileges the journey, a journey directed by senses and natural forces-wind, sun, vegetation, noise, sound-rather than a map. According to Deleuze and Guattari, no space is wholly striated or smooth: these tendencies exist in assemblages such as music, fabric and needlework, mathematics, and art in various relationships and ratios.

This partnership between smooth and striated spaces also exists within genres, I argue. Rhetorical genre scholar Bawarshi (2003) observes, for instance, that some genres, particularly literary genres, have a greater space for transgression and experimentation. Similarly, Medway (2002) suggests that "there are degrees of genreness, from tightly defined (or ossified...) to baggy and indeterminate" (p. 141). Different genres, then, have more or less smooth space, a space where writers may access what Weathers (1980) calls Grammar B, a style characterized by "variegation, synchronicity, discontinuity, ambiguity, and the like" (p. 8). The genre function-as Bawarshi (2003) labels the constitutive and regulative nature of genre-determines to what extent a genre is composed of striated and smooth space and where and how writers can play within the striations. New hybrid genres alter the relationship between the striated and the smooth, creating more smooth space for affective connection and stylistic exploration. By playing in the associative and ambiguous smooth spaces of genres, academic writers can "combine elements of the familiar and 
Volume 28, 2018

http://journals.sfu.ca/cjsdw

defamiliarize them" (Turner, 1982, p. 34) and trouble the distinction between the subjective and the objective, as Behar (1997/2014) calls on us to do.

In addition to determining the ratio between smooth and striated space in a genre, the genre function also regulates access to smooth space. Practicing vulnerable or alternative academic writing places all writers squarely within the sights of a favoured critique of our professors and our colleagues: this writing is too personal. Take, for instance, Bartholomae's (1995) position: he is wary of teaching students personal, expressive genres in the academic classroom; he views personal writing as "an expression of a desire for an institutional space free from institutional pressures, a cultural process free from the influence of culture, a historical moment outside history, an academic setting free from academic writing" (p. 64). Bartholomae (1995) fears that students in an expressive classroom will not develop a critical stance towards their commonplace ideas of the world: “I find [sentimental realism] a corrupt, if extraordinarily tempting genre. I don't want my students to celebrate what would then become the natural and inevitable details of their lives" (p. 71). Pedagogical prescriptions like Bartholomae's highlight the borderlands between the striated and smooth space, the urban and wild spaces of academic genres.

Despite the risk of criticism, some academics in the humanities (often in anthropology and sociology, but sometimes in other disciplines like English, writing studies, and history) have turned to vulnerable genres to explore the relationship between their lives and their academic work (Ellis, 1995, 2004; Tompkins, 1987; Williamson, 1997). Indeed, sociologist Ellis (2004) has described in detail a research method-autoethnography-which encourages the active exploration of the researcher's experiences. Some of these vulnerable and autoethnographic works have been published in the traditional academic journals and books. However, most of these academics have published their vulnerable writing tentatively after they have attained tenure. These established members of the discourse community-experts in the traditional genres-are given the latitude to play. Applied linguist Bhatia (1997) describes how these privileged discourse community members can use their expertise to play with the constraints of a genre:

Practicing a genre is almost like playing a game, with its own rules and conventions. Established genre participants ... are like skilled players, who succeed by their manipulations and exploitation of genre, rather than a strict compliance with the rules of the game. (p. 25-6) 
Volume 28, 2018

http://journals.sfu.ca/cjsdw

While some professional genres may allow novices to innovate under certain circumstances (Artemeva, 2005), novice writers who play in the smooth spaces of academic genres risk censure from the academic community because of their inexperience with the rules and conventions of the traditional genres and their limited status in the discourse community. Doloriert and Sambrook (2009) write, for instance, about the challenges faced by a doctoral candidate who submitted an autoethnographic work for examination. So while it is acceptable for well-established scholars to play with the smooth spaces of traditional academic writing, novice academics may not have this opportunity. Where does this leave novice academics? If vulnerable writing is a privilege of established discourse community members, in which genres can novice academics use smooth space to engage the conflicts and contradictions of the academic experience?

Here, then, was the crux of my dilemma: I am strongly drawn to alternative academic genres that I had discovered during this liminal phase of my academic journey. This scholarship resonates with me; working and writing in this way gave me a place to play, to associate and assimilate academic thinking within the broader landscape of my life. Here, I could access the original thought necessary for good scholarship. However, this type of writing and thinking puts me into the margins of the academy and into a place where my work might be dismissed. Could I negotiate this tension?

\section{Part 4: Reinvention}

The attached chairs and desks in the classroom are uncomfortable. We are older graduate students - many of my classmates have worked as educators in the school system for years, and I, too, am returning to graduate school in my middle age. Our older, less streamlined bodies wriggle and fidget like kindergarten students in these chairs. The professor clears his throat at the front of the classroom; our chairs scream against the linoleum floor as we turn our desks to face him.

"Your methodology needs to flow from your research context and purpose-you cannot and should not choose your method first," the professor reminds us as he returns our weekly assignments. I hold back my objections to the professor's statement. I've already asked too many irritating questions in this class: how can I write a literature review interesting to read? What if I want to write an alternative dissertation, using creative nonfiction strategies? Can I write an articlebased dissertation like my husband's students in an applied science field? Does your advice to publish six articles during our PhD still apply if I want to be a public intellectual? What should I write if I want to be a public intellectual? 
Volume 28, 2018

http://journals.sfu.ca/cjsdw

While the professor has been patient and generous in answering my questions, I know that I am just short of becoming the difficult student in this class, the one always poking at the institution's and the professor's sore spots. So I shift silently, uncomfortably in my hard plastic chair.

I've struggled with this course, required for my PhD program and designed to prepare us for the process of doctoral research. This course embodies what I feared about returning full time to the university: a post-positivist approach to research that is politely (but never quite overtly) suspicious of my work. To be honest, I'm surprised to encounter this in my next-to-last course in my degree. I have managed to create a dream doctoral program: an interdisciplinary program in education, writing studies, and communication supported by a thoughtful and kind supervisory team who understand that I'm not going to be a typical student. In contrast to this course, the other classes in my program have reflected a broader perspective on academic research.

“But isn't worldview an important consideration when choosing our methodological approach? And don't we have to think about our personal interests and talents?" Another student voices her objections to the professor's statements.

“I don't think personal preference should come into this. Attachment to a particular methodology or method might limit you from seeing a better approach." Several hands shoot up: a volley of objections. Many of my classmates study with experts in particular qualitative methods, and they are going to have something to say about the complex interaction between our worldview, our personal talents, methodology, and the world that we want to study. I duck my head, suppressing a smile; I'm happy that I'm not the only one at odds with this material.

Although I do not agree with everything this professor says, I do like him and value his expertise. Listening to him respond to my classmates' dissent, I realize that I am genuinely happy that I have decided to return to the university. I like these discussions; I like what I am reading; I like what I am thinking about. In light of these positive experiences and a more mature understanding of human institutions, my distrust of the university has softened, slowly dissolving in the currents of my thought.

"You know, I like it when you guys argue with me," the professor concludes our discussion amiably. "It means that you are listening and that you care." His collegiality makes me wonder about my own intransigence. Silently, I challenge myself: maybe you don't always have to resist so ferociously? Maybe you could try another research approach, broaden your horizons? Maybe trying a more traditional form of research will end this persistent defensiveness that you feel and seal your membership in this raucous but engaging community? 
Volume 28, 2018

http://journals.sfu.ca/cjsdw

And so, I falter.

When I chose to write a citation content analysis, I set aside my old grievances and applied for membership in the academy. With my citation content analysis, I hoped to prove that I could do the traditional work of the academy; this work would demonstrate, I thought, that my interest in alternative academic genres did not conceal an inability to write in traditional genres. What I didn't anticipate, perhaps naively, was how writing in the traditional IMRaD genre would impact my writing process and my access to the playful, smooth spaces of academic writing.

During my years on the margins of the academy, I had developed playful writing strategies that blended and combined academic analysis and personal narrative. When I wrote the experimental personal essay on my national identity and research questions, there was enough smooth space to allow my associative, assimilative approach, and this made my writing process joyful. Until I wrote my citation content analysis study, I did not understand how these playful strategies-the access to smooth spaces-had become intrinsic to my writing: they were not outside the final writing product. It was not an invention strategy that I used to generate ideas that would be then trimmed and reduced for a traditional genre. Rather, that play was intellectual work that found expression in those smooth spaces. This hybrid, alternative academic writing had become my "alpha genre," (Bawarshi, 2003, p. 99) and in that genre, with its different proportions of smooth and striated space, my writing flies.

The striations of the IMRaD genre, however, restricted my access to that play space. Like all genres, this traditional research article genre embodies the epistemological assumptions of the community that reads and writes it, and an understanding of symbolic representation is an important part of these assumptions. Bazerman (1988) argues that scientific discourse positions language as straightforward relationship between the signifier and signified: "Science tells us about nature; words and numbers are the symbols it uses to tell us...The only problem is the most practical one of making the symbols precise, unambiguous, univocal, to create a clear one-to-one correspondence between object and symbol" (p. 292). Because of these underlying assumptions about language, I had to remain alert as I wrote my citation content analysis. I had to filter out the poetic collision of words, the beat of a staccato sentence, the surprise of an unexpected association. This playful writing had no place, I felt, in the traditional work of the academy. A novice in this genre, I did not have the expertise to challenge these foundational assumptions. As a result, I got stuck in this writing, a difficulty that I ultimately overcame through stubbornness hardened with 
Volume 28, 2018

http://journals.sfu.ca/cjsdw

maturity. This same maturity, however, also prompts me to ask if this was my best scholarship and if the approbation of the broader academy is worth losing access (even temporarily) to those playful spaces in writing.

When we discuss play and creativity in relation to graduate student writing, we often focus on generative writing strategies like writing prompts or freewriting (see, for instance, Badenhorst, Moloney, Rosales, Dyer \& Ru, 2014 and Davies Turner \& Turner, 2015). We rarely consider how play happens within the smooth spaces of academic genres and how graduate students might access these spaces to resolve some of the conflicts and contradictions of the academy and to advance thinking in their disciplines. We argue that graduate student writing problems should not be framed as deficits (see, for instance, Badenhorst et al., 2014 and Haggis, 2006), but we seldom acknowledge that the strong normative forces of the academy may not lead to the vibrant and effective scholarship and writing we strive to promote; sometimes, student writing difficulties may be different but legitimate modes of thinking clashing with the expressive tools of the academy: smooth space running up against striated space.

Part of our work as writing scholars must be to open new smooth spaces in academic genreswildernesses of innovation and creativity-and to make these spaces accessible to graduate students, whose professional status is precarious and who can least afford to challenge community norms. This is not merely a question of making room for writerly students like me; we must also realign our writing practices to address the emerging contradictions and challenges of university work in Canada, many of which directly impact today's graduate students.

Since I began my graduate studies in the 1990s, graduate education in Canada has changed dramatically. While enrolment in PhD programs has increased by almost 70 percent since 2002, the number of traditional tenure track positions in Canada has not. As a result, less than $20 \%$ of doctoral graduates find tenure-track positions: these students are the exception, not the norm (Edge \& Munro, 2015). Moreover, just as professional outcomes shift for graduate students, universities also now recognize that they must work harder to engage a broader diversity of communities. Earlier models of research communication suggested that we could do so simply by translating our knowledge into lay language for less knowledgeable publics. However, as Myers (2003) points out, this deficit model of research communication is inherently unidirectional and assumes that the ignorant public needs only a simplified explanation of research findings to acquiesce to scientific authority. Public debates about climate change and about the relationship between vaccines and autism have demonstrated the limitations of this approach: our scientifically- 
Volume 28, 2018

http://journals.sfu.ca/cjsdw

oriented and tightly striated genres often do not change minds. Indeed, climate change communication scholars have concluded, like Geertz (2009) and Behar (1997/2014), that we need a new genre to negotiate these divides (Chess \& Johnson, 2008; Hulme, 2009; Moser, 2010). Opening up smooth space in academic genres is thus not just about permitting stylistic innovation: it is also about finding ways to overcome these emerging conflicts with and challenges to academic work.

Many Canadian universities have recognized these pressures and are adding extracurricular professional development programs, discussing alternative thesis and dissertation genres to better reflect the new outcomes of graduate programs and exploring better ways to engage communities (K. Campbell, personal communication). Writing studies scholars are, I believe, in a unique position to help create new writing spaces to support these efforts. To do so, we can build on our existing scholarship on genre, academic, and professional writing in the following ways.

First, we should explore student writing difficulties and community critiques of academic genres as areas of conflict and contradiction that may need to be resolved by opening up new smooth spaces in traditional academic genres or by developing new hybrid genres. Second, we should participate in current university discussions of alternative thesis and dissertation genres at our universities. While these initiatives are helpful—writing a dissertation-by-publication has certainly eased my dissertation journey-they may not acknowledge how the precariousness of graduate writing and prescriptive genres like dissertation preparation courses impact a student's willingness to innovate in research and writing. I entered my doctoral program in an ideal situation to write an alternative dissertation, and yet I bowed to the implicit social pressure of the academic community and chose to write a chapter in a traditional genre. (Fortunately, the hybrid nature of the dissertation-by-publication saved me from wrestling with this genre for the remainder of my dissertation and helped me to negotiate the multiple purposes and audiences of the dissertation that Paré, Starke-Myerring and McAlpine identify (2009).) We need to more thoroughly explore the question of how can we make these emerging genres more advantageous and accessible for the students who wish to write in them. Finally, we should model and share alternative academic writing in all levels of the academy including undergraduate work, graduate work, journal publications, and theses and dissertations. Because the genre function of traditional academic genres currently enforces a hierarchy between novice and expert writing and restricts access to smooth spaces based on this hierarchy, actively working against these limitations may shift the boundary between striated and smooth space in these genres. As a discipline, writing studies is 
Volume 28, 2018

http://journals.sfu.ca/cjsdw

already home to diverse methodologies and writing genres; other disciplines, however, are less open to this diversity and modelling these possibilities may help to create more smooth space and innovative scholarship within their genres.

"Smooth spaces are not in themselves liberatory," Deleuze and Guattari (1987) warn us. "But the struggle is changed or displaced in them, and life reconstitutes its stakes, confronts new obstacles, invents new spaces, switches adversaries. Never believe that a smooth space will suffice to save us" (p. 500). In other words, opening up these smooth spaces in academic writing will not resolve all of the conflicts and contradictions of academic life or set us loose to write in "[a] space free from institutional pressures, a cultural process free from the influence of culture, a historical moment outside history, and academic setting free from academic writing," as Bartholomae fears that it might (1995, p. 64). Rather, identifying and exploring smooth spaces will force us to acknowledge that academic genres, like universities, are inventions; they are rooted in historical developments, community needs, and community values. As individual writers and as academic communities, we can challenge, revise, rail against, subvert, and play with the limitations of these structures that we have developed. Insightful, creative, helpful scholarship may develop in these spaces as a result.

\section{Endnotes}

1. Correspondence may be addressed to nbray@ualberta.ca.

\section{Acknowledgements}

I would like to thank Katy Campbell, Karly Coleman, Marg Iveson, Betsy Sargent, and two reviewers for their helpful suggestions on drafts of this paper. This research was supported by a Social Sciences and Humanities Research Council Joseph-Armand Bombardier Canada Graduate Scholarship.

\section{References}

Artemeva, N. (2005). A time to speak, a time to act. Journal of Business and Technical Communication, 19(4), 389-421. doi:10.1177/105065190527830 
Volume 28, 2018

http://journals.sfu.ca/cjsdw

Badenhorst, C., Moloney, C., Rosales, J., Dyer, J., \& Ru, L. (2014). Beyond deficit: Graduate student research-writing pedagogies. Teaching in Higher Education, 20(1), 1-11. doi:10.1080/13562517.2014.945160

Bartholomae, D. (1985). Inventing the university. In M. Rose (Ed.), When a writer can't write: Studies in writer's block and other composing-process problems (pp. 134-165). New York: Guilford Press.

Bartholomae, D. (1995). Writing with teachers: A conversation with Peter Elbow. College Composition and Communication, 46(1), 62-71. doi:10.2307/358870

Bawarshi, A. S. (2003). Genre and the invention of the writer: Reconsidering the place of invention in composition. Logan, UT: Utah State University Press.

Bazerman, C. (1981). What written knowledge does - three examples of academic discourse. Philosophy of the Social Sciences, 11(3), 361-387. doi:10.1177/004839318101100305

Bazerman, C. (1988). Shaping written knowledge: The genre and activity of the experimental article in science. Madison, WI: University of Wisconsin Press.

Behar, R. (2014). Anthropology that breaks your heart: The vulnerable observer. Beacon Press.

Berkenkotter, C., \& Huckin, T. N. (1995). Genre knowledge in disciplinary communication: Cognition/culture/power. Hillsdale, NJ: Lawrence Erlbaum.

Bhatia, V. K. (1997). The power and politics of genre. World Englishes, 16, 359-371. doi: 10.1111/1467-971X.00070

Bishop, W. (1997). Elements of alternate style: Essays on writing and revision. Portsmouth, NH: Boynton/Cook Publishers.

Bizzell, P. (1999). Hybrid academic discourse: What, why, how. Composition Studies, 27(Fall), 7-21.

Bray, N. (1997). "The art of transgression or the transgression of art." Unpublished manuscript.

Chess, C., \& Johnson, B. (2008). Information is not enough. In S. C. Moser \& L. Dilling (Eds.), Creating a climate for change (pp. 223-233). Cambridge, UK: Cambridge University Press.

Doloriert, C., \& Sambrook, S. (2009). Ethical confessions of the "I" of autoethnography: The student's dilemma. Qualitative Research in Organizations and Management: An International Journal, 4(1), 27-45. doi:10.1108/17465640910951435

Deleuze, G., \& Guattari, F. (1987). A thousand plateaus: Capitalism and schizophrenia. Minneapolis, MN: University of Minnesota Press.

Devitt, A. J. (2004). Writing genres. Carbondale, IL: Southern Illinois University Press.

Dias, P., Freedman, A., Medway, P., \& Paré, A. (2013). Worlds apart acting and writing in academic and workplace contexts. Mahwah, NJ: Taylor and Francis. 
Volume 28, 2018

http://journals.sfu.ca/cjsdw

Edge, J., \& Munro, D. (2015). Inside and outside the academy. Ottawa: Conference Board of Canada.

Elbow, P. (2000). Everyone can write: Essays toward a hopeful theory of writing and teaching writing. New York, NY: Oxford University Press.

Ellis, C. (1995). A story of love and chronic illness: Final negotiations. Philadelphia, PA: Temple University Press.

Ellis, C. (2004). The ethnographic I: A methodological novel about autoethnography. Walnut Creek, CA: AltaMira Press.

Engeström, Y. (1987). Learning by expanding: An activity-theoretical approach to developmental research. Helsinki: Orienta-Konsultit Oy.

Freadman, A. (1987). Anyone for tennis? In I. Reid (Ed.), The place of genre in learning: Current debates (pp. 91-124). Deakin University (Australia): Centre for in Literary Education.

Geertz, C. (2009). Two countries, four decades, one anthropologist: After the fact. Harvard University Press.

Haggis, T. (2006). Pedagogies for diversity: Retaining critical challenge amidst fears of 'dumbing down'. Studies in Higher Education, 521-535. doi: 10.1080/03075070600922709

Hairston, M. (1986). When writing teachers don't write: Speculations about probable causes and possible cures. Rhetoric Review, 5(1), 62-70. doi: 10.1080/07350198609359136

Hulme, M. (2009). Understanding controversy, inaction and opportunity: Why we disagree about climate change. New York, NY: Cambridge University Press.

Limerick, P. N. (2005). Dancing with professors: The trouble with academic prose. In M. E. Sargent \& C. C. Paraskevas (Eds.), Conversations about writing: Eavesdropping, inkshedding, and joining in (pp. 226-233). Toronto, CA: Nelson.

Medway, P. (2002). Fuzzy genres and community identities: The case of architecture students' sketchbooks. In R. Coe, L. Lingard, \& T. Teslenko (Eds.), The rhetoric and ideology of genre: Strategies for stability and change (pp. 123-153). Cresskill, NJ: Hampton Press.

Miller, C. R. (1984). Genre as social action. Quarterly Journal of Speech, 70, 151-176.

Moser, S. C. (2010). Communicating climate change: History, challenges, process and future directions. Wiley Interdisciplinary Reviews: Climate Change, 1(1), 31-53. doi:10.1002/wcc.11

Murray, D. (1991). All writing is autobiographical. College Composition and Communication, 42(1), 66-74. doi:10.2307/35754

Myers, G. (2003). Discourse studies of scientific popularization: Questioning the boundaries. Discourse Studies, 5(2), 265-279. doi:10.1177/1461445603005002006 
Volume 28, 2018

http://journals.sfu.ca/cjsdw

Paré, A. (2002). Genre and identity: Individuals, institutions, and ideology. In R. M. Coe, L. Lingard, \& T. Teslenko (Eds.), The rhetoric and ideology of genre: Strategies for stability and change (pp. 5771). Cresskill, NJ: Hampton Press.

Paré, A., Starke-Meyerring, D., \& McAlpine, L. (2009). The dissertation as multi-genre: Many readers, many readings. In C. Bazerman, A. Bonini, \& D. de Carvalho Figueiredo (Eds.), Genre in a changing world (pp. 179-193). Fort Collins, CO: Parlor Press.

Royster, J. J., Kirsch, G., \& Bizzell, P. (2012). Feminist rhetorical practices new horizons for rhetoric, composition, and literacy studies. Carbondale, IL: Southern Illinois University Press.

Russell, D. R. (1997). Rethinking genre in school and society: An activity theory analysis. Written Communication, 14(4), 504-554. doi: 10.1177/0741088397014004004

Savin-Baden, M. (2008). Learning spaces: Creating opportunities for knowledge creation in academic life. New York, NY: McGraw Hill.

Schryer, C. F. (1994). The lab vs. the clinic: Sites of competing genres. In A. Freedman \& P. Medway (Eds.), Genre and the new rhetoric (pp. 105-124). London: Taylor and Francis.

Spellmeyer, K. (1989). Foucault and the freshman writer: Considering the self in discourse. College English, 51(7), 715-729. doi:10.2307/37791

Swales, J. M. (1990). Genre analysis: English in academic and research settings. New York, NY: Cambridge University Press.

Sword, H. (2012). Stylish academic writing. Cambridge, MA: Harvard University Press.

Tompkins, J. (1987). Me and my shadow. New Literary History, 19(1), 169-178. doi:10.2307/469310

Turner, V. (1982). From ritual to theatre: The human seriousness of play. New York, NY: Performing Arts Journal Publications.

Weathers, W. (1980). An alternate style: Options in composition. Rochelle Park, NJ: Hayden Book Company.

Williamson, J. (1997). Wounds not scars: Lynching, the national conscience, and the American historian. The Journal of American History. 83(4), 1221-1253. doi:10.2307/2952899 